\title{
Biodiversity and distribution of macroinfauna assemblages on sandy beaches along the Gulf of Cadiz (SW Spain)
}

\author{
M. José Reyes-Martínez ${ }^{1}$, M. Carmen Ruiz-Delgado ${ }^{1}$, Juan Emilio Sánchez-Moyano ${ }^{2}$, \\ Francisco José García-García ${ }^{1}$ \\ ${ }^{1}$ Departamento de Sistemas Físicos, Químicos y Naturales, Universidad Pablo de Olavide, Ctra. Utrera km 1, \\ 41013 Sevilla, Spain.E-mail: mjreymar@upo.es \\ ${ }_{2}^{2}$ Departamento de Zoología, Universidad de Sevilla, Av. Reina Mercedes 6, 41012 Sevilla, Spain.
}

\begin{abstract}
Summary: In the current study, the macroinfauna communities inhabiting 12 sandy beaches along the Spanish coast of the Gulf of Cadiz were describe in order to characterize their unexplored biodiversity, their zonation patterns and their environmental features. A total of 66 macroinfauna taxa were recorded on 12 sandy beaches, ranging from 4 to 33 species. Density reached 848 individual per $\mathrm{m}^{2}$. The individual zonation pattern ranged from two to three zones, regardless of the morphodynamic state. A common zonation pattern of the whole set of beaches was established, comprising three across-shore biological zones. Generally, the supralittoral zone was typified by the air-breathing amphipod Talitrus saltator and coleopterans; the middle zone was dominated by true intertidal species, such as Haustoriidae amphipods (Haustorius arenarius), Cirolanidae isopods (Eurydice affinis), Spionidae polychaetes (Scolelepis spp.) and nemerteans; and the lower or sublittoral zone was typified by Pontoporeiidae amphipods, mysids and spionid polychaetes. Sediment moisture, average grain size, organic matter content and elevation were the main predictor variables of zonation patterns. We used the conservation and recreation potential indices to show how this information can be useful for coastal management. Most beaches studied show a score above 5 on the conservation index, so the beaches have a reasonable potential for conservation management.
\end{abstract}

Keywords: sandy beaches; benthic macroinfauna; zonation pattern; environmental variables; Gulf of Cadiz, coastal management.

Biodiversidad y distribución de las comunidades de macroinfauna en playas arenosas del Golfo de Cádiz (SO España)

Resumen: En el presente estudio, se describen las comunidades de macroinfauna de doce playas arenosas de la costa española del Golfo de Cádiz con el objetivo de caracterizar su biodiversidad, sus patrones de zonación, y sus características ambientales. Un total de 66 taxones de macroinfauna fueron registrados en las playas de estudio, oscilando entre 4 y 33 especies, mientras que la densidad total fue de 848 individuos por $\mathrm{m}^{2}$. El patrón de zonación individual varió de dos a tres zonas, independientemente del estado morfodinámico de la playa. Se estableció un patrón de zonación común de todo el conjunto de playas, formado por tres zonas biológicas. En general, la zona supralitoral fue tipificada por el anfípodo Talitrus saltator y diversas familias de coleópteros. La zona media fue dominada por verdaderas especies intermareales, como anfípodos de la famila Haustoriidae (Haustorius arenarius), isópodos cirolánidos (Eurydice affinis), poliquetos (Scolelepis spp.) y nemertinos. La zona sublitoral se caracterizó por anfípodos de la familia Pontoporeiidae, misidáceos y poliquetos espiónidos. La humedad del sedimento, el tamaño medio de grano, el contenido en materia orgánica y la elevación fueron las principales variables influyentes en los patrones de zonación. Por último, toda esta información fue integrada para la aplicación de los índices de Conservación y Recreación, para mostrar cómo esta información puede ser útil para la gestión costera. La mayoría de las playas mostraron una puntuación superior a 5 en el Índice de Conservación, indicando un razonable potencial para la conservación.

Palabras clave: playas arenosas; macroinfauna béntica; patrones de zonación; variables ambientales; Golfo de Cádiz; gestión costera.

Citation/Como citar este artículo: Reyes-Martínez M.J., Ruíz-Delgado M.C., Sánchez-Moyano J.E., García-García F.J. 2015. Biodiversity and distribution of macroinfauna assemblages on sandy beaches along the Gulf of Cadiz (SW Spain). Sci. Mar. 79(3): 367-377. doi: http://dx.doi.org/10.3989/scimar.04133.30A

Editor: R. Sardà.

Received: July 31, 2014. Accepted: May 22, 2015. Published: July 3, 2015.

Copyright: () 2015 CSIC. This is an open-access article distributed under the Creative Commons Attribution-Non Commercial Lisence (by-nc) Spain 3.0. 


\section{INTRODUCTION}

The Gulf of Cadiz is located in the southwestern Iberian Peninsula, between Cape St Vincent (Portugal) and the Strait of Gibraltar (Spain), which connects the Atlantic Ocean and the Mediterranean Sea. The Spanish coastal area of this gulf stretches some $300 \mathrm{~km}$, between Ayamonte (Huelva province) and Tarifa (Cadiz province). The area is influenced mainly by the mouths of the rivers Guadiana, Piedras, Tinto, Odiel, Guadalete and Guadalquivir and is dominated by estuarine zones and extensive sandy beaches, many of which are faced by discontinuous rocky-shore platforms (Benavente et al. 2002), especially on the Cadiz coast.

The general air circulation in the Gulf of Cadiz is predominantly anticyclonic, with short-term variation influenced by winds. This region is characterized by a mean water-surface temperature ranging from $18^{\circ} \mathrm{C}$ to $22^{\circ} \mathrm{C}$, a salinity range of $36.3 \%$ o to $36.5 \%$ o, an average nitrate, phosphate and silicate concentration of about $0.33,0.08$ and $1.37 \mu \mathrm{M}$, respectively (Anfuso et al. 2010 ), and a chlorophyll $a$ concentration of around 10$40 \mathrm{mg} \mathrm{m}^{-2}$ (Prieto et al. 1999). These features provide a suitable habitat for the development of several species, which makes this system a very diverse and productive area (Sobrino et al. 1994). Many species inhabiting the Gulf of Cadiz have economic value, so it is considered an area with great socio-economic importance for fisheries and shellfish gathering (Torres et al. 2013). Frequently, these species use sandy shores as nursery areas for juveniles (Baldó and Drake 2002), feeding on invertebrates (Speybroeck et al. 2007), and they can use biogenic structures (e.g. tubes, mounds and burrows) constructed by the invertebrates as a refuge from predation (Allen-Brooks et al. 2006).

The sandy shores provide a large range of services, such as sediment and water storage, decomposition of organic matter and pollutants, wave dissipation, water filtration and purification, nutrient recycling, maintenance of biodiversity and a functional link between marine and terrestrial environments, where macroinfauna plays a key role (Defeo et al. 2009). Furthermore, the favourable climatic conditions in Spain make the coastal environments attractive to tourism for several months a year and beaches are a major economic resource (Anfuso et al. 2003).

Despite the importance of sandy beaches and the scale of the coastline areas occupied in the study, data on biotic and abiotic characteristics are scant. Along the Spanish Gulf of Cadiz, past studies have focused on studying the morphodynamics of sandy beaches in restricted areas (Anfuso et al. 2003) and the morphological changes associated with meteorological events (Buitrago and Anfuso 2011). The few studies that have described the fauna inhabiting the beaches have focused on macroinfauna from estuarine beaches (Mayoral et al. 1994) or on the supralittoral arthropods associated with wrack deposits (Ruiz-Delgado et al. 2014). There is therefore a considerable lack of information on macroinfauna communities in this region.

Increasing human interest in sandy beaches has exacerbated unsustainable practices that involve destruc- tion of these natural environments (Defeo et al. 2009). Identifying and mapping the macroinfauna inhabiting sandy beaches is an essential step for establishing effective management and conservation tools for a better use of these marine environments (McLachlan et al. 2013, Rolet et al. 2015, Schlacher et al. 2014) and for estimating the potential response of biota to future habitat changes.

The aim of this study is to provide the first description of macroinfauna communities inhabiting sandy beaches and their environmental characteristics. To this end, (1) the physical and morphodynamic characteristics of 12 sandy beaches along the Gulf of Cadiz coastline were defined; (2) the macroinfauna communities inhabiting sandy beaches were characterized; (3) the zonation pattern of macroinfauna was determined; and (4) the influence of environmental factors on the zonation patterns was explored.

Finally, all this information was employed to calculate two quantitative indicators following McLachan et al. (2013). These indices are used to assess beach condition and suitability for different uses, from which guidelines for planning, management and monitoring can be derived.

\section{MATERIALS AND METHODS}

\section{Study area}

The study area comprised 12 sandy beaches along the Spanish coast of the Gulf of Cadiz, from Hoyo beach $\left(37^{\circ} 11^{\prime} 55^{\prime}\right.$ 'N, $\left.07^{\circ} 17^{\prime} 45^{\prime \prime} \mathrm{W}\right)$ near the Portuguese border to Lances beach $\left(36^{\circ} 02^{\prime} 31^{\prime \prime} \mathrm{N}, 05^{\circ} 38^{\prime} 08.031^{\prime \prime} \mathrm{W}\right)$ in the area near the Strait of Gibraltar (Fig. 1).

\section{Sampling procedures}

For all 12 beaches, macroinfauna sampling was carried out in six replicated transects haphazardly separated by a 100-m-long stretch in the central area of each beach during low tide between March and May 2011.

In each transect, macroinfauna samples were collected at 10 equally spaced shore levels extending from above the drift line (level 10) to the low swash zone (level 1) with a 25-cm-diameter plastic core of a depth of $20 \mathrm{~cm}$. Transect length depended on each beach's width. A total of 60 samples were collected within a total sampled area of $3.75 \mathrm{~m}^{2}$ per beach. On temperate beaches this area is considered sufficient to collect $90 \%$ of all the macroinfauna (Jaramillo et al. 1995). Samples were sieved on site through a 1-mm mesh sieve, collected in labelled plastic bags and preserved in $70 \%$ ethanol stained with Rose Bengal. Additionally, one sediment sample was taken at each sampling level with a plastic tube $(3.5 \mathrm{~cm}$ diameter) buried $15 \mathrm{~cm}$ deep to analyse the mean grain size, sorting coefficient (Trask 1950), sand moisture and organic matter of the sediment.

In the laboratory, the macroinfauna was quantified and identified to the lowest taxonomic level possible. The mean grain size was determined following the method proposed by Guitián and Carballas (1976). This method discriminates different granulometric fractions 
when the sediment composition is mainly sand and the pelitic fraction is low (less than 5\%). Sand moisture was determined by measuring the weight loss after drying the samples at $90^{\circ} \mathrm{C}$. The organic matter content of the sediment fraction $<0.5 \mathrm{~mm}$ was estimated as the difference between dry sediment weight and sediment weight after calcination at $500^{\circ} \mathrm{C}$.

To characterize the morphodynamic state, the relative tidal range (Masselink and Short 1993), the beach index (McLachlan and Dorvlo 2005), the beach state index (McLachlan et al. 1993) and the dimensionless fall-velocity parameter (Dean's parameter; Dean 1973) were used. The beach face slope was estimated by the height difference according to Emery (1961). The height and wave period, temperature and tidal range were taken from average annual data from the SIMAR oceanographic database of Puertos del Estado (Spanish Ministry of Public Works) (http://www.puertos.es/eses/oceanografia/Paginas/portus.aspx).

\section{Conservation and recreation potential indices}

To characterize the main use of beaches, the conservation index $(\mathrm{CI})$ and the recreation potential index (RI) were applied following McLachlan et al. (2013). For each indicator a simple scoring system was developed based on three key drivers in order to evaluate the potential/suitability of a beach for conservation and/or recreation. CI takes into account 1 ) the extent, nature and condition of the dunes, their well-developed vegetation and their connection with the beach; 2) the presence of iconic and endangered species; and 3) the macrobenthic community abundance and species richness. In contrast, RI is based on 1) available infrastructures to support recreational activities (beach access, toilets, etc.); 2) beach safety and health status; and 3) physical carrying capacity. CI and RI values range from 0 to 10 , in increasing order of conservation value or recreation potential.

\section{Data analysis}

Univariate analyses were used to characterize the fauna communities present on each beach studied, calculating the Margalef richness index $(d)$, the ShannonWiener diversity index ( $\left.H^{\prime}\right)$ and the Pielou evenness index (J'), using the PRIMER software package.

The zonation pattern on each beach studied was identified using cluster analysis, based on the Bray-Curtis similarity matrix, followed by a similarity profile test (SIMPROF) (Clarke and Gorley 2006), to evaluate the significance of the classification $(\mathrm{p}<0.05)$. Previously, abundance data were fourth-root transformed to downweight the contribution of the major abundant species.

Once the zonation patterns had been defined on individual beaches, a modal pattern of zonation was established for the entire set of beaches. To this end, species from each sampling level were pooled based on zones identified by cluster analysis. Then, a single matrix of "species $\times$ zone" for each beach was generated and all of them were combined into a global matrix. This global biological matrix was fourth-root transformed and subjected to non-metric

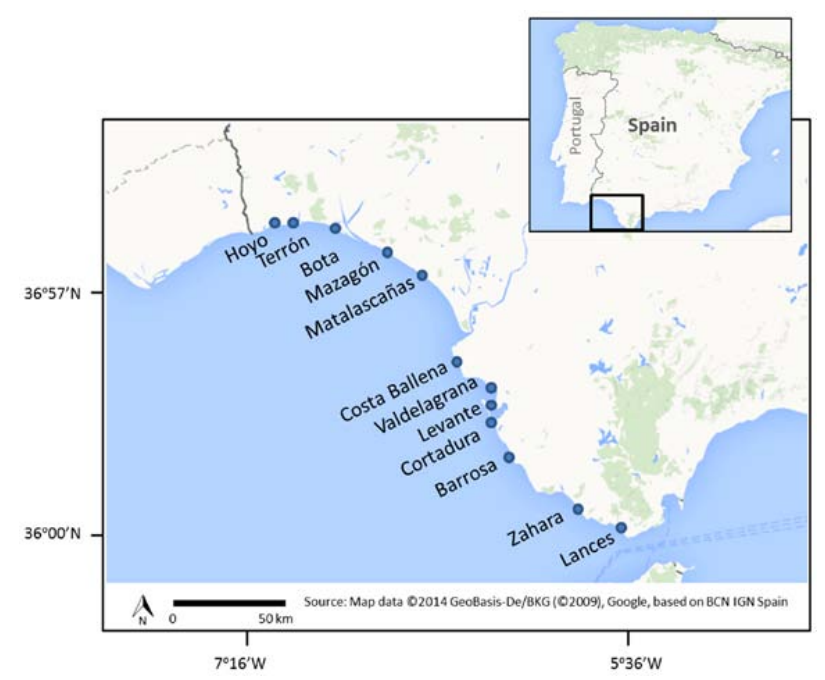

Fig. 1. - Study area showing the 12 sandy beaches sampled.

multi-dimensional scaling ordination (n-MDS). Furthermore, the similarity percentages analysis (SIMPER) was performed in order to find the typifying species in each identified zone for the entire set of beaches along the Gulf of Cadiz. Beaches that did not have a clear zonation pattern were excluded from these analyses. All multivariate analyses were performed with PRIMER-E v 6.1 (PRIMER-E Ltd) (Clarke and Warwick 2001).

To determine associations of macroinfauna communities with environmental variables, a canonical correspondence analysis (CCA) was applied (TerBraak 1986). First, a global biological matrix was submitted to detrended correspondence analysis (DCA) in order to measure the gradient lengths and to ensure an unimodal species response. Gradient length of the first axis was greater than 3.0 SD, and a CCA ordination method was used. For this analysis, only the most abundant species ( $>6 \%$ of total contribution in each biological zone identified) were taken into account after fourthroot transformation.

The environmental parameters matrix was transformed $(\log (x+1))$ and standardized prior to reducing extreme values and providing better canonical coefficient comparisons. Only variables significantly related to the fauna variation were included $(p<0.05)$; to this end, each variable was analysed separately and its significance was tested using a Monte Carlo permutation test (999 permutations) (TerBraak 1995).

In CCA analysis, the statistical significance of canonical eigenvalues and the significance of the first two axes were tested by a Monte Carlo test (999 permutations). DCA and CCA were carried out with the statistical software package PC-ORD (McCune and Medford 1997).

\section{RESULTS}

\section{Beach characteristics}

The physical and morphodynamic characteristics of the 12 beaches studied are shown in Table 1. According 
Table 1. - Physical characterization of sampled beaches. L, beach length (m); Mgs, median grain size (mm); OM, organic matter content (\%); RTR, Relative tide range; BI, beach index; BSI, beach state index.

\begin{tabular}{lccccccccccc}
\hline Beaches & $\mathrm{L}$ & Slope $(1 / \mathrm{m})$ & Mgs & Sand type & Sorting & Dean & RTR & BI & BSI & OM \\
\hline Hoyo & 2800 & 10.99 & 0.65 & coarse sand & 1.54 & 1.6 & 2.27 & 1.36 & 0.92 & 0.62 \\
Terrón & 3500 & 29.52 & 0.42 & medium sand & 1.45 & 2.53 & 2.27 & 2.09 & 1.09 & 0.48 \\
Bota & 3800 & 46.59 & 0.22 & fine sand & 1.33 & 5.23 & 2.7 & 2.51 & 1.36 & 0.89 \\
Mazagón & 5500 & 15.84 & 0.49 & medium sand & 1.57 & 2.1 & 2.41 & 1.75 & 1.05 & 0.62 \\
Matalascañas & 4200 & 13.97 & 0.41 & medium sand & 1.34 & 2.59 & 2.34 & 1.77 & 1.1 & 0.31 \\
Costa Ballena & 4500 & 29.99 & 0.23 & fine sand & 1.35 & 5.91 & 2.27 & 2.31 & 1.43 & 0.68 \\
Valdelagrana & 1880 & 17.69 & 0.21 & fine sand & 1.6 & 6.8 & 2.28 & 2.11 & 1.48 & 1.19 \\
Levante & 4600 & 26.46 & 0.22 & fine sand & 1.43 & 6.32 & 2.49 & 2.25 & 1.42 & 0.75 \\
Cortadura & 2500 & 84.31 & 0.20 & fine sand & 1.25 & 7.73 & 2.02 & 2.81 & 1.55 & 0.81 \\
Barrosa & 4000 & 17.6 & 0.47 & medium sand & 1.55 & 2.42 & 2.05 & 1.76 & 1.03 & 2.92 \\
Zahara & 2900 & 11.5 & 0.51 & coarse sand & 1.75 & 2.26 & 1.58 & 1.43 & 0.93 & 0.83 \\
Lances & 4300 & 24.76 & 0.23 & fine sand & 1.35 & 6.41 & 1.07 & 1.94 & 1.19 & 0.57 \\
\hline
\end{tabular}

to the tidal range and relative tidal range, the beaches were categorized as mesotidal, dominated by waves. The beaches showed a wide range of morphodynamic types, classified by Dean's parameter as intermediate (Terrón, Mazagón, Matalascañas, Barrosa and Zahara), dissipative (Bota, Costa Ballena, Valdelagrana, Levante, Cortadura, and Lances) and reflective (Hoyo). Beach state index values classified most beaches as intermediate to dissipative, with high energy levels, except for Hoyo and Zahara, which were intermediate beaches with low to medium energy levels.

\section{Macroinfauna}

A total of 63 macroinfauna taxa were recorded from the beaches of the Gulf of Cadiz (Appendix 1). Crustaceans were the most diverse taxa, with 23 species, followed by polychaetes ( 22 species), insects and molluscs ( 9 and 8 species, respectively). Appendix 1 shows the total abundance, total species, Margalef species richness, Shannon-Wiener diversity index and Pielou evenness index. Bota and Levante had the highest richness, with 33 and 24 species, respectively, while the lowest value
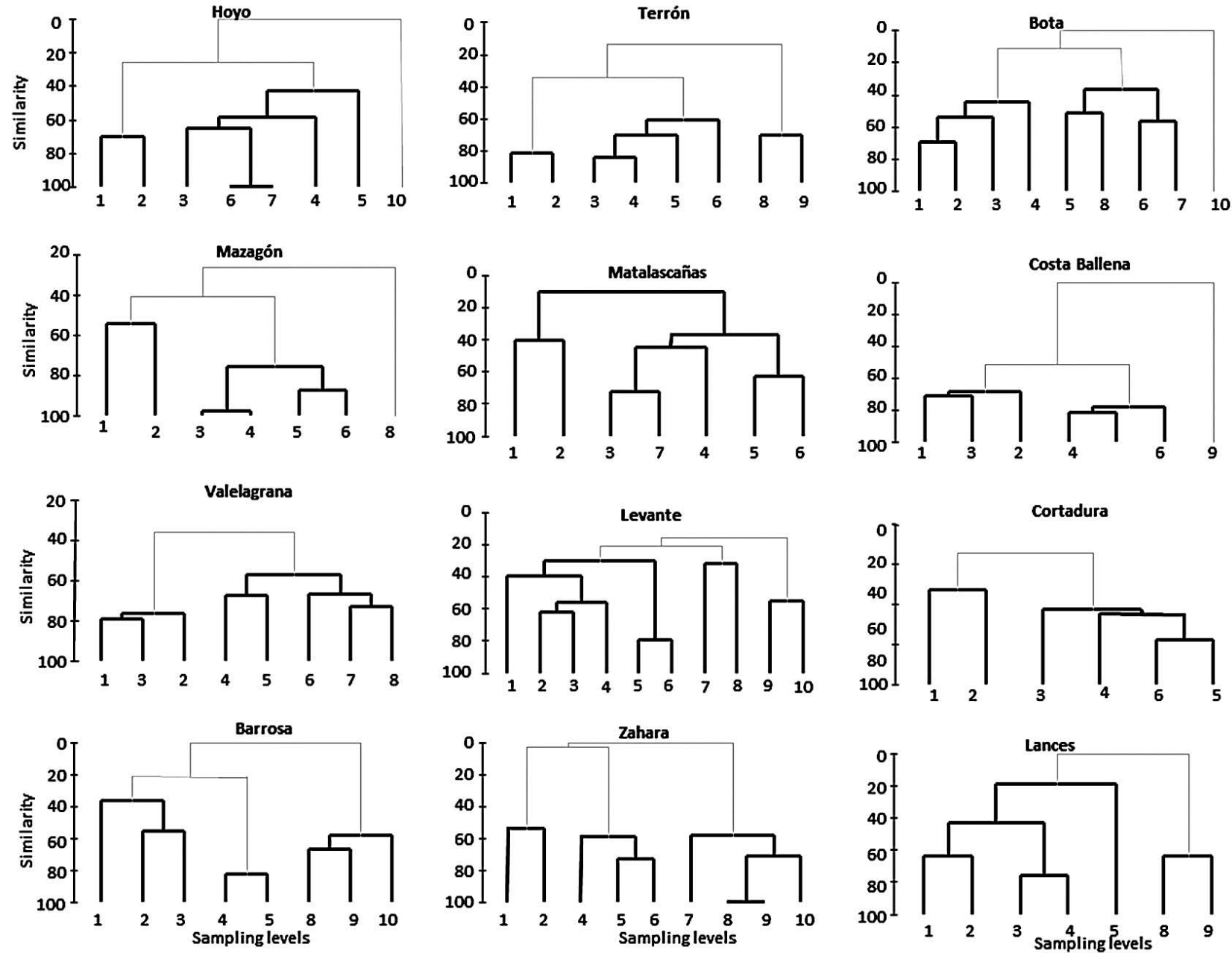

Fig. 2. - Zonation pattern in each studied beach defined by similarity profile (SIMPROF). Grey lines represent significant evidence of community structure $(\mathrm{P}<0.05)$. Black lines indicate no significant evidence. 


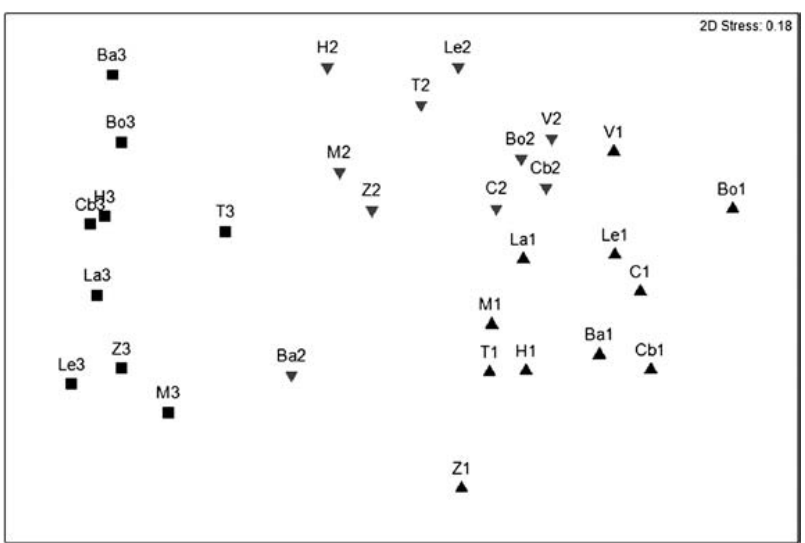

Fig. 3. - n-MDS ordination for the global zonation pattern. Black triangles represent the lower zones, grey inverted triangles the middle zones and black quadrates the upper zones of the studied beaches.

was found at Matalascañas (4 species). Density was also highly variable, ranging from 23 to 249 individuals per $\mathrm{m}^{2}$. The lowest diversity value $\left(\mathrm{H}^{\prime}\right)$ was observed at Matalascañas beach (0.40), while the highest was found at Levante (2.68). The evenness index ranged from 0.29 at Matalascañas to 0.86 at Lances beach.

Scolelepis spp., Pontocrates arenarius and Haustorius arenarius were the most frequent species. The polychaete was present on $100 \%$ of the total beaches sampled, while the amphipods were present on $90 \%$. In terms of abundance, polychaetes of the genus Scolelepis were dominant, accounting for $28 \%$ of total abundance, followed by the amphipod Haustorius arenarius, which accounted for $15 \%$ of the total.

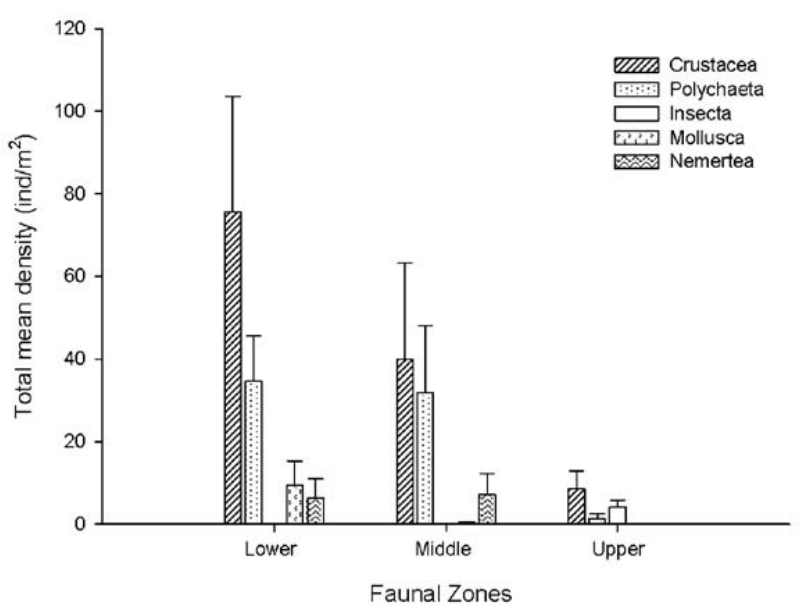

Fig. 4. - Mean total density $( \pm \mathrm{SE})$ of the taxa found in the lower, middle and upper zones.

\section{Zonation}

Across-shore species distribution on each beach studied is shown in Figure 2. Cluster ordination and the SIMPROF test identified two biological zones at Valdelagrana and Cortadura and Lances, and three biological zones at Hoyo, Terrón, Bota, Mazagón, Costa Ballena, Levante, Barrosa and Zahara. Exceptionally, Matalascañas did not show a clear zonation pattern. For this analysis, the sampling levels where no species were present were removed.

A global zonation pattern of the entire set of beaches from the Spanish Gulf of Cadiz coastline was derived from the individual across-shore species distribution;

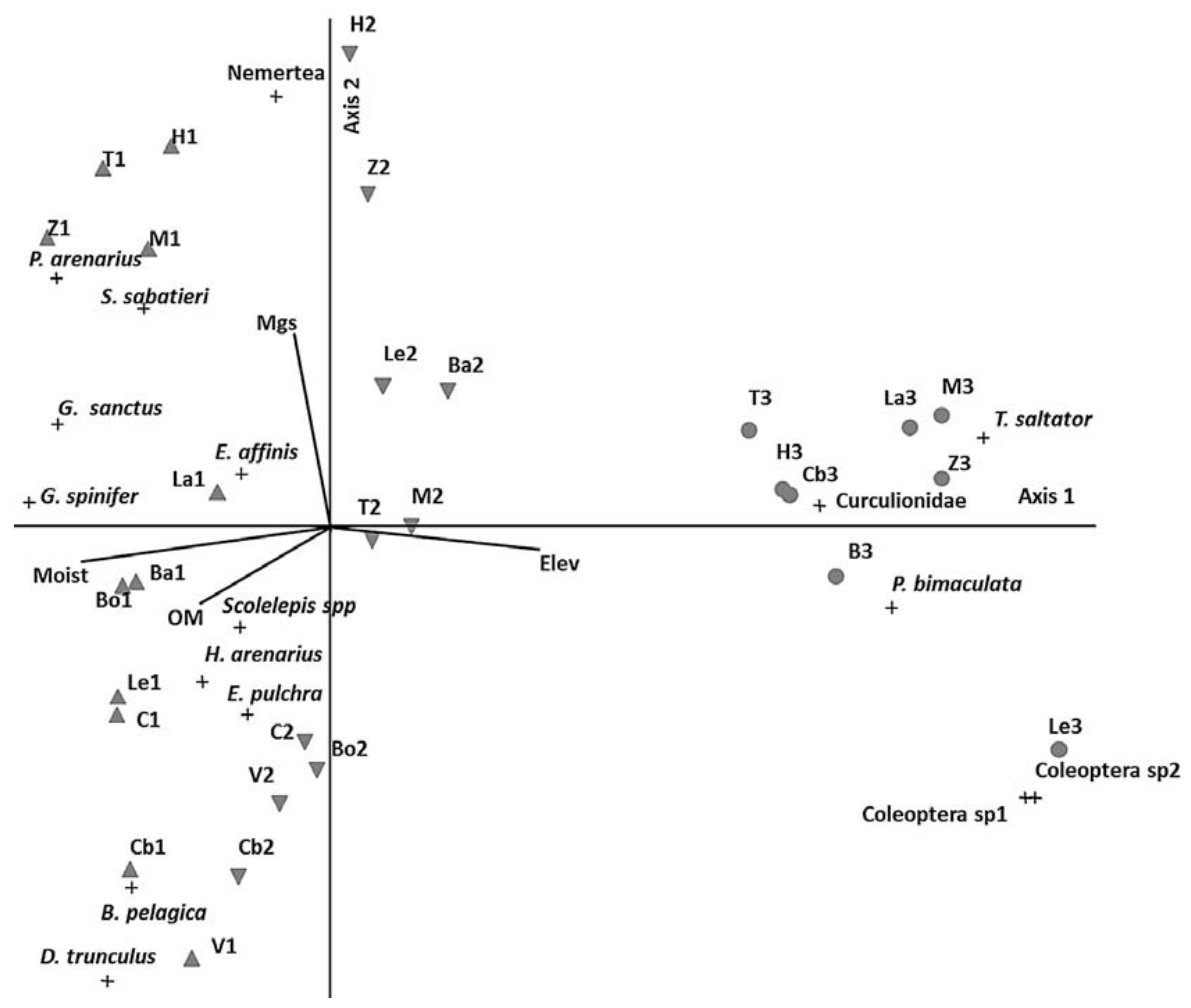

Fig. 5. - Triplot resulting from CCA analysis. Crosses show the most abundant species in each zone. The lower zones are represented by triangles, the middle zones by inverted triangles and the upper zones by circles. Arrows represents explanatory variables (Moist, sand moisture; $\mathrm{Mgs}$, median grain size; Elev, elevation; OM, organic matter content). 
Table 2. - Conservation index (CI) and recreation potential index (RI) scores for beaches.

\begin{tabular}{|c|c|c|c|c|c|c|c|c|}
\hline Beach name & Dune status & Iconic species & Macro-benthos & $\mathrm{CI}$ & Infrastructure & Safety health & $\begin{array}{l}\text { Carrying } \\
\text { capacity }\end{array}$ & RI \\
\hline Ноуо & $\begin{array}{l}4 \\
\text { Well developed, } \\
\text { little disturbance }\end{array}$ & $\begin{array}{c}1 \\
\text { Low numbers, } \\
\text { not nesting }\end{array}$ & $\begin{array}{c}1 \\
\text { Intermediate }\end{array}$ & 6 & $\begin{array}{c}1 \\
\text { No infrastructure, } \\
\text { limited access }\end{array}$ & $\begin{array}{l}3 \\
\text { Low hazard, } \\
\text { clean and } \\
\text { pollution free }\end{array}$ & $\begin{array}{c}2 \\
\text { Extensive beach } \\
\text { with wide } \\
\text { backshore }\end{array}$ & 6 \\
\hline Terrón & $\begin{array}{c}4 \\
\text { Well developed, } \\
\text { little disturbance }\end{array}$ & $\begin{array}{c}2 \\
\text { Present in good } \\
\text { numbers, may } \\
\text { be nesting }\end{array}$ & $\begin{array}{c}1 \\
\text { Intermediate }\end{array}$ & 7 & $\begin{array}{c}1 \\
\text { No infrastructure, } \\
\text { limited access }\end{array}$ & $\begin{array}{l}3 \\
\text { Low hazard, } \\
\text { clean and } \\
\text { pollution free }\end{array}$ & $\begin{array}{c}1 \\
\text { Intermediate }\end{array}$ & 5 \\
\hline Bota & $\begin{array}{c}4 \\
\text { Well developed, } \\
\text { little disturbance }\end{array}$ & $\begin{array}{c}1 \\
\text { Low numbers, } \\
\text { not nesting }\end{array}$ & $\begin{array}{c}2 \\
\text { Species rich and } \\
\text { abundant }\end{array}$ & 7 & $\begin{array}{c}1 \\
\text { No infrastructure, } \\
\text { limited access }\end{array}$ & $\begin{array}{c}3 \\
\text { Low hazard, } \\
\text { clean and } \\
\text { pollution free }\end{array}$ & $\begin{array}{c}2 \\
\text { Extensive beach } \\
\text { with wide } \\
\text { backshore }\end{array}$ & 6 \\
\hline Mazagón & $\begin{array}{c}4 \\
\text { Well developed, } \\
\text { little disturbance }\end{array}$ & $\begin{array}{c}2 \\
\text { Present in good } \\
\text { numbers, may } \\
\text { be nesting }\end{array}$ & $\begin{array}{c}1 \\
\text { Intermediate }\end{array}$ & 7 & $\begin{array}{c}1 \\
\text { No infrastructure, } \\
\text { limited access }\end{array}$ & $\begin{array}{c}2 \\
\text { Moderate hazard } \\
\text { and clean }\end{array}$ & $\begin{array}{c}1 \\
\text { Intermediate }\end{array}$ & 4 \\
\hline Matalascañas & $\begin{array}{c}0 \\
\text { Absent }\end{array}$ & $\begin{array}{c}0 \\
\text { Absent }\end{array}$ & $\begin{array}{c}1 \\
\text { Intermediate }\end{array}$ & 1 & $\begin{array}{c}5 \\
\text { Excellent access } \\
\text { and amenities }\end{array}$ & $\begin{array}{c}2 \\
\text { Moderate hazard } \\
\text { and clean }\end{array}$ & $\begin{array}{c}0 \\
\text { Limited, pocket } \\
\text { beach, no } \\
\text { backshore }\end{array}$ & 7 \\
\hline Costa Ballena & $\begin{array}{l}\text { 3 } \\
\text { Disturbed but } \\
\text { largely intact }\end{array}$ & $\begin{array}{c}1 \\
\text { Low numbers, } \\
\text { not nesting }\end{array}$ & $\begin{array}{c}2 \\
\text { Species rich and } \\
\text { abundant }\end{array}$ & 6 & $\begin{array}{c}3 \\
\text { Good access, some } \\
\text { amenities }\end{array}$ & $\begin{array}{c}3 \\
\text { Low hazard, } \\
\text { clean and } \\
\text { pollution free }\end{array}$ & $\begin{array}{c}2 \\
\text { Extensive beach } \\
\text { with wide } \\
\text { backshore }\end{array}$ & 8 \\
\hline Valdelagrana & $\begin{array}{c}0 \\
\text { Absent }\end{array}$ & $\begin{array}{c}1 \\
\text { Low numbers, } \\
\text { not nesting }\end{array}$ & $\begin{array}{c}2 \\
\text { Species rich and } \\
\text { abundant }\end{array}$ & 3 & $\begin{array}{c}5 \\
\text { Excellent access } \\
\text { and amenities }\end{array}$ & $\begin{array}{c}3 \\
\text { Low hazard, } \\
\text { clean and } \\
\text { pollution free }\end{array}$ & $\begin{array}{c}1 \\
\text { Intermediate }\end{array}$ & 9 \\
\hline Levante & $\begin{array}{c}4 \\
\text { Well developed, } \\
\text { little disturbance }\end{array}$ & $\begin{array}{c}3 \\
\text { Significant } \\
\text { nesting area for } \\
\text { marine birds }\end{array}$ & $\begin{array}{c}2 \\
\text { Species rich and } \\
\text { abundant }\end{array}$ & 9 & $\begin{array}{c}1 \\
\text { No infrastructure } \\
\text { and limited access }\end{array}$ & $\begin{array}{c}3 \\
\text { Low hazard, } \\
\text { clean and } \\
\text { pollution free }\end{array}$ & $\begin{array}{c}1 \\
\text { Intermediate }\end{array}$ & 5 \\
\hline Cortadura & $\begin{array}{c}1 \\
\text { Severely } \\
\text { disturbed }\end{array}$ & $\begin{array}{c}0 \\
\text { Absent }\end{array}$ & $\begin{array}{c}2 \\
\text { Species rich and } \\
\text { abundant }\end{array}$ & 3 & $\begin{array}{c}2 \\
\text { Modest } \\
\text { infrastructure, } \\
\text { reasonable access }\end{array}$ & $\begin{array}{c}2 \\
\text { Moderate hazard } \\
\text { and clean }\end{array}$ & $\begin{array}{c}1 \\
\text { Intermediate }\end{array}$ & 5 \\
\hline Barrosa & $\begin{array}{c}2 \\
\text { Extensive } \\
\text { disturbance }\end{array}$ & $\begin{array}{c}0 \\
\text { Absent }\end{array}$ & $\begin{array}{c}2 \\
\begin{array}{c}\text { Species rich and } \\
\text { abundant }\end{array}\end{array}$ & 4 & $\begin{array}{c}2 \\
\text { Modest } \\
\text { infrastructure, } \\
\text { reasonable access }\end{array}$ & $\begin{array}{c}3 \\
\text { Low hazard, } \\
\text { clean and } \\
\text { pollution free }\end{array}$ & $\begin{array}{c}2 \\
\text { Extensive beach } \\
\text { with wide } \\
\text { backshore }\end{array}$ & 7 \\
\hline Zahara & $\begin{array}{c}4 \\
\text { Well developed, } \\
\text { little disturbance }\end{array}$ & $\begin{array}{c}2 \\
\text { Present in good } \\
\text { numbers, may } \\
\text { be nesting }\end{array}$ & $\begin{array}{c}1 \\
\text { Intermediate }\end{array}$ & 7 & $\begin{array}{c}2 \\
\text { Modest } \\
\text { infrastructure, } \\
\text { reasonable access }\end{array}$ & $\begin{array}{c}2 \\
\begin{array}{c}\text { Moderate hazard } \\
\text { and clean }\end{array}\end{array}$ & $\begin{array}{c}2 \\
\text { Extensive beach } \\
\text { with wide } \\
\text { backshore }\end{array}$ & 6 \\
\hline Lances & $\begin{array}{c}4 \\
\text { Well developed, } \\
\text { little disturbance }\end{array}$ & $\begin{array}{c}2 \\
\text { Present in good } \\
\text { numbers, may } \\
\text { be nesting }\end{array}$ & $\begin{array}{c}1 \\
\text { Intermediate }\end{array}$ & 7 & $\begin{array}{c}2 \\
\text { Modest } \\
\text { infrastructure, } \\
\text { reasonable access }\end{array}$ & $\begin{array}{c}2 \\
\text { Moderate hazard } \\
\text { and clean }\end{array}$ & $\begin{array}{c}2 \\
\text { Extensive beach } \\
\text { with wide } \\
\text { backshore }\end{array}$ & 6 \\
\hline
\end{tabular}

therefore, faunal zones identified at each beach were gathered for a global MDS ordination (Fig. 3). SIMPER analysis performed on this ordination showed a degree of similarity of $40 \%$ between all lower zones, where Pontocrates arenarius, Gastrosaccus sanctus and Scolelepis spp. showed the highest percentages of presences (17.8\%, $17.2 \%$ and $11.0 \%$, respectively). The middle zones showed a similarity of about $30 \%$. Polychaetes of the genus Scolelepis (37.70\%), the isopod Eurydice affinis $(26.40 \%)$, the amphipod Haustorius arenarius $(11.56 \%)$, and nemerteans $(9.95 \%)$ highlighted the similarity in faunal composition between all middle zones. Finally, the upper zones showed a $20 \%$ similarity and the typifying species were the air-breathing amphipod Talitrus saltator (56.7\%) and coleopterans (37\%).

Biologically, density values decreased from the lower to the upper zone. In the lower and middle zones the most abundant taxa were crustaceans and polychaetes, while in the upper zones, besides crustaceans, insects were dominant (Fig. 4).

\section{Relationship between environmental variables and macroinfauna}

Environmental variables significantly related to fauna variations, tested by Monte Carlo permutation test, were elevation $(\mathrm{p}=0.002)$, sand moisture $(\mathrm{p}=0.001)$, organic matter content $(\mathrm{p}=0.015)$ and grain size $(p=0.001)$. However, these predictor variables were not strongly correlated $\left(\mathrm{r}^{2}<0.5\right)$. The Monte Carlo test for the set of environmental variables was significant for both axes $(\mathrm{p}=0.001)$ and for eigenvalues $(\mathrm{p}=0.001)$ showing a significant relationship between biological data and predictor environmental variables. 


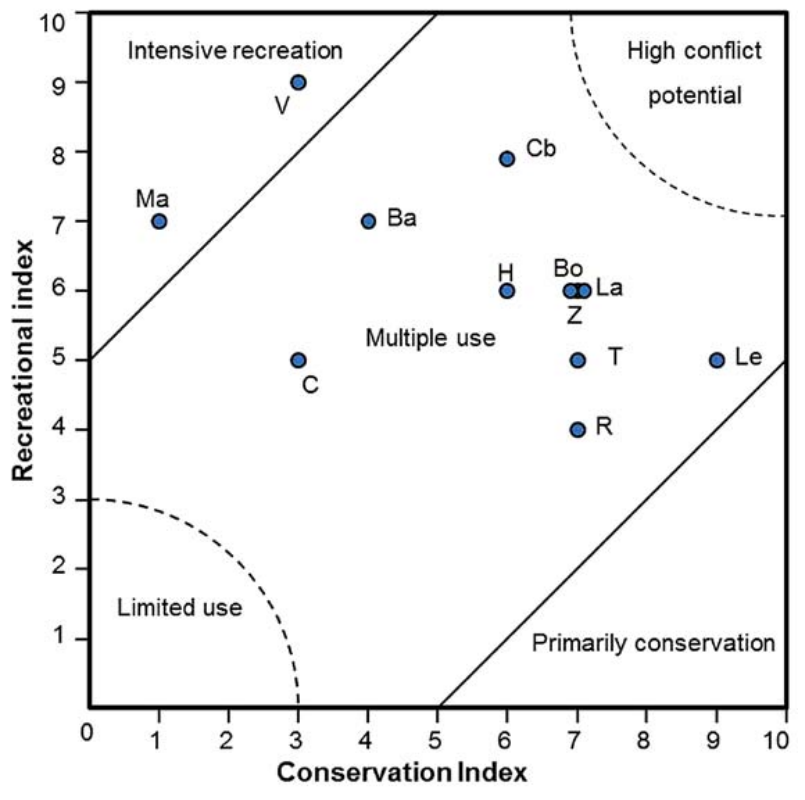

Fig. 6. - Location of each beach listed in Table 2 relative to its conservation index and recreation potential index scores. The plot shows the demarcation of beaches for intensive recreation, conservation and multi-purpose use. H, Hoyo; T, Terrón; Bo, Bota; M, Mazagón; Ma, Matalascañas; Cb, Costa Ballena; V, Valdelagrana; Le, Levante; C, Cortadura; Ba, Barrosa; Z, Zahara; La, Lances.

The CCA results show that the total variation of data was 2.49 (inertia), while the total variation explained was 0.802 (the sum of all canonical eigenvalues). Pearson species-environmental correlations were relatively high: 0.93 for Axis 1 and 0.82 for Axis 2. The first axis (accounting for $66 \%$ of the total explained variation) correlated positively with elevation (0.745) and negatively with sand moisture $(-0.887)$ and organic matter content $(-0.465)$. The second axis (accounting for $0 \%$ of the explained variation) correlated mainly with medium-sized grain (0.806).

The ordination diagram of CCA (Fig. 5) showed a gradient of zones (lower, middle, and upper) marked mainly by the first axis and showed that crustaceans (Bathyporeia pelagica, Eurydice affinis, E. pulchra, Gastrosaccus sanctus, G. spinifer, Haustorius arenarius and Pontocrates arenarius) and Polychaeta (Scolelepis spp.) responded positively to sand moisture and organic matter content but negatively to elevation, increasing their density to the left along the first axis. Coleopterans and Talitrus saltator exhibited the opposite pattern. Density of nemerteans was the least explained by these environmental variables.

The nemerteans $P$. arenarius and $G$. sanctus also responded positively to medium-coarse grain size, while the density of Bathyporeia pelagica, Donax trunculus and Coleoptera sp1 was more influenced by fine grain size, due to their distribution along the second axis.

\section{Conservation against recreational potential}

Table 2 provides a summary of 12 cases of beach usage by means of CI and RI scores and the ensuing management strategy is illustrated in Figure 6. Most beaches are in the multiple-use category, indicating that they have high conservation and recreation values. Only Matalascañas and Valdelagrana are in the intensive recreation category, with high RI values (7 and 9, respectively).

\section{DISCUSSION}

\section{Macroinfauna}

Sandy beaches are extremely dynamic ecosystems with hostile conditions for life, so the number of taxa adapted to living under these conditions is expected to be low compared with other coastal systems. However, the macroinfauna biodiversity found in sandy beaches of the Spanish coast of the Gulf of Cadiz were relatively high (from 4 to 33 species). This value is similar to those reported in nearby latitudes, such as the 9 to 31 species found in northern Spain (Rodil et al. 2006), the 27 to 30 species found on the western coast of Portugal (Gonçalves et al. 2009), and the 4 to 24 species found on Moroccan sandy beaches (Bayed 2003).

The beaches showed a wide range of morphodynamic types and a general increasing trend in species richness from reflective to dissipative beaches was observed, in agreement with McLachlan et al. (1993). Bota beach showed the highest species richness and abundance. This beach, located near the mouth of the Piedras River, where the influence of wave action is lower, is one of the most sheltered of the entire set of beaches studied, as is also reflected in the relative tidal range, which showed high values on this sandy beach. The high richness and abundance values found on Bota beach supports the general trend of biotic variables to increase with exposure, as reported by other authors (Dexter 1983, Jaramillo and MacLachlan 1993, Rodil et al. 2007). Abundance and richness of macroinfauna are directly related to food supply (Rodil et al. 2012), so it is also possible that Piedras river mouth increases food availability, enabling the establishment and development of more species.

Crustaceans, polychaetes and molluscs were usually dominant among the macroinfauna of sandy beaches (McLachlan and Brown 2006). In our study, amphipod and isopod crustaceans and spionid polychaetes were the most abundant and included diverse taxa. In fact, $74 \%$ of all individuals collected belong to six species of these groups: Bathyporeia pelagica, Haustorius arenarius, Pontocrates arenarius, Siphonoecetes sabatieri, Eurydice affinis and Scolelepis spp. The dominant and most frequent species occurring on every beach studied were polychaetes of the genus Scolelepis. This genus has a wide geographical distribution (Souza and Borzone 2000) and is also very abundant on many Atlantic beaches (Papageorgiou et al. 2006, Degraer et al. 2003, Barros et al. 2001).

Little importance is given to nemerteans, which are normally not considered typical taxa on sandy beaches, due to residual contributions that they exhibit, although this taxon is considered a useful bio-indicator (HerreraBachiller et al. 2008). For example, the nemerteans Lienus acutifrons and Psammamphiporus elongatus were affected by the "Prestige" oil spill on Galician 
sandy beaches, so they could be a good indicators of beach quality (Herrera-Bachiller et al. 2008, Puerta et al. 2010). On sandy beaches of southwestern Spain, Nemertean abundance was similar to that of molluscs, showing high occurrences (67\% of the sampled beaches), highlighting the importance of nemerteans at these latitudes. Similarly, Talitrus saltator was frequently found on the beaches studied. This 'sand-hopper' is recognized as a good biomonitor of trace-metal pollution and the effect of human trampling (Ugolini et al. 2008).

\section{Macroinfauna zonation}

The zonation of macroinfauna, defined as the distribution of species throughout the intertidal zone on sandy beaches, has been undertaken around the world (Defeo et al. 1992, Jaramillo et al. 2000, Schlacher and Thompson 2013). Macroinfauna across-shore distribution is highly variable, ranging from one to five biological zones, although three are most common (see Schlacher and Thompson 2013). In the current study, $67 \%$ of total beaches showed three distinct zones and $25 \%$ showed two. This pattern was different to that found on beaches in northern Spain, where macroinfauna was divided into two main zones (Rodil et al. 2006), and on Moroccan sandy beaches, where four zones were identified according to Salvat's scheme (Salvat 1964, Bayed 2003).

Jaramillo et al. (1993) determined that intermediate and dissipative beaches include three faunal zones, whereas the reflective beaches had only two. Along the Spanish coast of the Gulf of Cadiz, this pattern was not found. In fact, the more dissipative beaches showed two biological zones, while beaches closest to the reflective state (Hoyo and Mazagón) had three zones. In general, the number of zones alternated, independently of Dean's parameter. Thus, no clear evidence was found to support the contention that the number of zones is closely related to morphodynamics. These results corroborate the conclusion drawn by Schlacher and Thompson (2013), who detected no significant correlation between habitat metric (habitat dimensions, sediment properties, and morphodynamic state) and the number of fauna zones.

Although the number of biological zones varied among beaches, a common zonation pattern was established for the entire set of beaches studied. This was done in order to characterize the most typical species inhabiting each zone. The general pattern showed three biological zones according to the zonation scheme of Dahl (1952). In general, the supralittoral zone was typified by air-breathing amphipods (Talitrus saltator) and coleopterans. The middle zone was dominated by true intertidal species, such as Haustoriidae amphipods (Haustorius arenarius), Cirolanidae isopods (Eurydice affinis), Spionidae polychaetes (Scolelepis spp.) and nemerteans. The lower or sublittoral zone was typified by amphipods belonging to the Pontoporeiidae family: mysids, and spionid polychaetes. The distribution of the species in each zone is in agreement with findings on other nearby temperate sandy beaches, such as those along the northern coasts of Spain, Tunisia, and Mo- rocco (Rodil et al. 2006, Pérez-Domingo et al. 2008, Bayed 2003)

Diversity and densities of individuals increase towards the lower zones. This is a general feature found in numerous studies of sandy beaches worldwide (Jaramillo et al. 1993, Gonçalves et al. 2009, Rodil et al. 2006). Some authors have determined that this pattern could be due to a reflection of the high sub-tidal diversity and short periods of air exposure, thus allowing more species to inhabit zones closest to the seawater (Degraer et al. 1999, Aerts et al. 2004). The high abundance found in the lower areas of all the beaches studied evidences how important these environments are as potential sources of food for other predatory species (fish and birds).

\section{Relationship between environmental variables and macroinfauna}

Distribution of macroinfauna is related to the tolerance of these communities to environmental variables (McLachlan and Brown 2006). Although the relationship between species and the environment could change with the scale of study (Rodil et al. 2012), abiotic predictor variables at the local scale were examined.

Beach slope and grain size have been identified as main factors controlling macroinfauna distribution throughout the intertidal zone (McLachlan et al. 1993, Jaramillo and MacLachlan 1993). Results from CCA analysis showed that sand moisture and organic matter content, in addition to elevation and grain size, were the main environmental variables controlling the macroinfauna distribution across the shore on sandy beaches of the Gulf of Cadiz coast.

Lower and middle zones showed an internal gradient influenced mainly by average grain size. Species inhabiting these zones were Pontocrates arenarius, Siphonoecetes sabatieri and nemerteans, closely related to coarse grain size, while Donax trunculus and Bathyporeia pelagica were related to fine grain size.

The most abundant species in upper zones, the talitrid amphipod Talitrus saltator and coleopterans, were correlated positively with elevation but negatively with sand moisture and organic matter content. Grain size was not a good explanatory variable for these species. In fact, Ugolini et al. (2008) found no relationship between sand-hopper abundance and sand-grain size. Although these species showed significant relationships with abiotic variables, other factors not taken into account could affect their distribution. For example, it has been reported that stranded material (e.g. macrophytes and macroalgae) provides a physical structure that can be used as a shelter or breeding site and as a food source by supralittoral arthropods (Olabarria et al. 2007) and the age of these deposits plays a significant role in the structure of upper-shore assemblages (RuizDelgado et al. 2014).

\section{Conservation and recreation potential indices}

The conservation and recreation potential indices developed by McLachlan et al. (2013) are useful tools for determining the most suitable beach management 
approach, providing a set of management principles that can easily be followed, even with limited resources. In these cases, mapping plays a key role for the collection of information and has been identified as a principal step towards management and conservation policies (Rolet et al. 2015). In addition, the implementation of these indices provides the broadest characterization of sandy beaches, not only based on physical features, since sandy beaches are also social and ecological environments.

In this work, 12 case studies illustrate the application of the CI and RI indices. Although these indices include five categories, our beaches are grouped mainly into two: intensive recreation and multiple use. Most beaches have shown scores above 5 on the CI, so they have a reasonable potential for conservation. For example, Terrón, Mazagón and Levante beaches, categorized by these indices as of multiple use, have a high conservation potential. Coastal management policies should therefore be designed to promote measures for the conservation of these environments. On the other hand, only Matalascañas and Valdelagrana, have a high recreation potential, which can be exploited with appropriate management strategies or the possible re-evaluation of existing measures that reduce the CI value, for example.

In conclusion, the beaches on the Spanish coastline along the Gulf of Cadiz are characterized by high biodiversity, including major bio-indicator species, and by a clear zonation of macroinfauna. The overall distribution pattern involves three biological zones: the supralittoral zone, characterized by air-breathing amphipods and coleopterans; the middle zone, characterized by Haustoriidae amphipods, Cirolanidae isopods, Spionidae polychaetes and nemerteans; and the sublittoral zone, characterized by amphipods belonging to the Pontoporeiidae family, mysids and spionid polychaetes. The across-shore distribution of the macroinfauna is influenced primarily by sand moisture, organic matter content, elevation and grain size. Other factors such as wrack deposit and organic inputs from rivers and estuaries could influence the abundance and distribution of macroinfauna inhabiting sandy beaches. Therefore, future studies are needed to elucidate whether the presence of stranded material could affect the global zonation patterns on sandy beaches. The recreation and conservation indices showed that the studied beaches have multiple functionalities, given their social, physical, morphodynamic and biotic features, although many of them have a high potential for conservation that needs to be managed.

\section{ACKNOWLEDGEMENTS}

We would like to thank the "Los Toruños" Natural Park (Cadiz) and its staff for the facilities provided during sampling. This work was supported by the incentive programme for excellent research projects financed by the government of Andalucía (P09- HUM-4717). This project also supported a PhD Grant awarded to the first author. M.C. Ruiz-Delgado was supported by the Spanish Ministry of Education via a pre-doctoral grant (FPU) (AP-2009-3906).

\section{REFERENCES}

Aerts K., Vanagt T., Degraer S., et al. 2004. Macroinfaunal community structure and zonation of an Ecuadorian sandy beach (Bay of Valdivia). Belg. Zool. 134: 15-22.

Allen-Brooks R., Purdy C.N., Bell S.S. et al. 2006. The benthic community of the eastern US continental shelf: A literature synopsis of benthic faunal resources.Cont. Shelf Res. 26: 804-818. http://dx.doi.org/10.1016/j.csr.2006.02.005

Anfuso G., Martínez del Pozo J.A., Gracia F.J., et al. 2003. Longshore distribution of morphodynamic beach states along an apparently homogeneous coast in SW Spain. J. Coast. Conservat. 9: 49-56.

http://dx.doi.org/10.1652/1400-0350(2003)009[0049:LDOMB S]2.0.CO;2

Anfuso E., Ponce R., González-Castro C., et al. 2010. Coupling between the thermohaline, chemical and biological fields during summer 2006 in the northeast continental shelf of the Gulf of Cadiz (SW Iberian Peninsula). Sci. Mar. 74S1: 47-56. http://dx.doi.org/10.3989/scimar.2010.74s1057

Bayed A. 2003. Influence of morphodynamic and hydroclimatic factors on the macroinfauna of Moroccan sandy beaches. Estuar. Coast. Shelf Sci. 58S: 71-82 http://dx.doi.org/10.1016/S0272-7714(03)00050-7

Baldó F., Drake P. 2002. A multivariate approach to the feeding habits of small fishes in the Guadalquivir Estuary. J. Fish Biol. 61: 21-32. http://dx.doi.org/10.1111/j.1095-8649.2002.tb01758.x

Barros F., Borzone C.A., Rosso S. 2001. Macroinfauna of six beaches near Guaratuba Bay, Southern Brazil. Braz. Arch. Biol. Techn. 44: 351-364 http://dx.doi.org/10.1590/S1516-89132001000400005

Benavente J., Del Río L., Anfuso G., et al. 2002. Utility of morphodynamic characterisation in the prediction of beach damage by storms. J. Coast. Res. 36: 56-64.

Buitrago N.R., Anfuso G. 2011. Morphological changes at Levante Beach (Cadiz, SW Spain) associated with storm events during the 2009-2010 winter seasons. J. Coast. Res. 64: 1886-1890.

Clarke K.R., Gorley R.N. 2006. PRIMER v6: user manual/tutorial. PRIMER-E, Plymouth, UK, 192 pp.

Clarke K.R. Warwick R.M. 2001. Change in Marine Communities: An Approach to Statistical Analysis and Interpretation, second ed. PRIMER-E, Plymouth, UK, 172 pp.

Dahl E. 1952. Some aspects of the ecology and zonation of the fauna on sandy beaches. Oikos 4: 1-27. http://dx.doi.org/10.2307/3565072

Dean R.G. 1973. Heuristic models of sand transport in the surf zone. Proceedings of a Conference on Engineering Dynamics in the Surf Zone (Sydney): 208-214.

Defeo O., Jaramillo E., Lyonnet A. 1992. Community structure and intertidal zonation of the macroinfauna on the Atlantic coast of Uruguay. J. Coast. Res. 8: 830-839.

Defeo O., McLachlan A., Schoeman D.S., et al. 2009. Threats to sandy beach ecosystems: A review. Estuar. Coast. Shelf Sci. 81: 1-12. http://dx.doi.org/10.1016/j.ecss.2008.09.022

Degraer S., De Neve, L., Mouton, I. et al. 1999. Zonation and community structure of the macrobenthos of a macrotidal, ultra-dissipative sandy beach: Summer-Winter comparison. Estuaries, 22(3B): 742-752. http://dx.doi.org/10.2307/1353107

Degraer S., Volckaert A., Vincx M. 2003. Macrobenthic zonation patterns along a morphodynamical continuum of macrotidal, low tide bar/rip and ultra-dissipative sandy beaches. Estuar. Coast. Shelf Sci. 56: 459-468. http://dx.doi.org/10.1016/S0272-7714(02)00195-6

Dexter D.M. 1983. Community structure of intertidal sandy beaches in New South Wales, Australia. In: McLachlan, A. and Erasmus T. (eds), Sandy Beaches as Ecosystems. Springer Netherlands, pp. 461-472. http://dx.doi.org/10.1007/978-94-017-2938-3 34

Emery K.O. 1961. A simple method of measuring beach profiles. Limnol. Oceanogr. 6: 90-93. http://dx.doi.org/10.4319/10.1961.6.1.0090

Gonçalves S.C., Anastácio P.M., Pardal A.M., et al. 2009. Sandy beach macroinfaunal communities on the western coast of Portugal-Is there a steady structure under similar exposed conditions? Estuar. Coast. Shelf Sci. 81: 555-568. http://dx.doi.org/10.1016/j.ecss.2008.12.004

Guitián F., Carballas J. 1976. Técnicas de análisis de suelos. Pico Sacro. Santiago de Compostela, España, 288 pp. 
Herrera-Bachiller A., García-Corrales P., Roldan C., et al. 2008. The ignored but common nemertine from the Galician beaches (Spain) Psammamphiporus elongatus, affected by the Prestige oil spill. Mar. Ecol. 29: 43-50. http://dx.doi.org/10.1111/j.1439-0485.2007.00199.x

Jaramillo E., McLachlan A. 1993. Community and population response of the macroinfauna to physical factors over a range of exposed sandy beaches in south-central Chile. Estuar. Coast. Shelf Sci., 37: 615-624. http://dx.doi.org/10.1006/ecss.1993.1077

Jaramillo E., McLachlan A, Coetzee P. 1993. Intertidal zonation patterns of macroinfauna over a range of exposed sandy beaches in south-central Chile. Mar. Ecol. Prog. Ser., 101: 105-118. http://dx.doi.org/10.3354/meps101105

Jaramillo E., McLachlan A., Dugan J. 1995. Total sample area and estimates of species richness in exposed sandy beaches. Mar. Ecol. Prog. Ser. 119: 311-314. http://dx.doi.org/10.3354/meps119311

Jaramillo E., Duarte C., Contreras H. 2000. Sandy beaches macroinfauna from the coast of Ancud, Isla Chiloé, southern Chile. Rev. Chil. Hist. Nat. 73: 771-786 http://dx.doi.org/10.4067/S0716-078X2000000400019

Masselink G., Short A.D. 1993. The effect of tide range on beach morphodynamics and morphology: a conceptual beach model. J. Coast. Res. 9: 785-800.

Mayoral M.A., López-Serrano L, Viéitez J.M. 1994. Macroinfauna bentónica intermareal de 3 playas de la desembocadura del río Piedras (Huelva, España). Bol. R. Soc. Esp. Hist. Nat. 91: 231-240.

McCune B., Medford M.J. 1997. PC-ORD. Multivariate analysis of ecological data, Version 3 for Windows. MjM Software Design, Gleneden Beach, Oregon.

McLachlan A., Brown A.C. 2006. The ecology of sandy shores. Elsevier, Burlington.

McLachlan A., Dorvlo A. 2005. Global patterns in sandy beach macrobenthic communities. J. Coast. Res. 21: 674-687. http://dx.doi.org/10.2112/03-0114.1

McLachlan A., Jaramillo E., Donn T.E., et al. 1993. Sandy beach macroinfauna communities and their control by the physical environment: a geographical comparison. J. Coast. Res. 15: 27-38.

McLachlan A., Defeo O., Jaramillo E., et al. 2013. Sandy beach conservation and recreation: Guidelines for optimising management strategies for multi-purpose use. Ocean Coast. Manage. 71: 256-268. http://dx.doi.org/10.1016/j.ocecoaman.2012.10.005

Papageorgiou N., Arvanitidis C., Eleftheriou A. 2006. Multicausal environmental severity: A flexible framework for microtidal sandy beaches and the role of polychaetes as an indicator taxon. Estuar. Coast. Shelf Sci. 70: 643-653. http://dx.doi.org/10.1016/j.ecss.2005.11.033

Olabarria C., Lastra M., Garrido J. 2007. Succession of macroinfauna on macroalgal wrack of an exposed sandy beach: Effects of patch size and site. Mar. Environ. Res. 63: 19-40. http://dx.doi.org/10.1016/j.marenvres.2006.06.001

Pérez-Domingo S., Castellanos C., Junoy J. 2008. The sandy beach macroinfauna of Gulf of Gabés (Tunisia). Mar. Ecol. 29: 51-59. http://dx.doi.org/10.1111/j.1439-0485.2007.00201.x

Prieto L., García C.M., Corzo A., et al. 1999. Phytoplankton, bacterioplankton and nitrate reductase activity distribution in relation to physical structure in the northern Alborán Sea and Gulf of Cadiz (southern Iberian Peninsula). Bol. Inst. Esp. Oceanogr. 15: 401-411.

Puerta P., Andrade S.C.S., Junoy J. 2010. Redescription of Lineus acutifrons Southern, 1913 (Nemertea: Pilidiophora) and comments on its phylogenetic position. J. Nat. Hist. 44: 2363-2378. http://dx.doi.org/10.1080/00222933.2010.504895

Rodil I.F., LastraM., Sánchez-Mata, A.G. 2006. Community structure and intertidal zonation of the macroinfauna in intermediate sandy beaches in temperate latitudes: North coast of Spain. Estuar. Coast. Shelf Sci. 67: 267-279.

http://dx.doi.org/10.1016/j.ecss.2005.11.018

Rodil I.F., Lastra M., López J. 2007. Macroinfauna community structure and biochemical composition of sedimentary organic matter along a gradient of wave exposure in sandy beaches (NW Spain). Hidrobiología 579: 301-316. http://dx.doi.org/10.1007/s10750-006-0443-2

Rodil I.F., Compton T.J., Lastra M. 2012. Exploring macroinvertebrate species distributions at regional and local scales across a sandy beach geographic continuum. PloS One (7)6: e39609. http://dx.doi.org/10.1371/journal.pone.0039609

Rolet C., Spilmont N., Dewarumez J.M. 2015. Linking macrobenthic communities structure and zonation patterns on sandy shores: Mapping tool toward management and conservation perspectives in Northern France. Cont. Shelf. Res. 99: 12-25. http://dx.doi.org/10.1016/j.csr.2015.03.002

Ruiz-Delgado M.C., Vieira J.V., Veloso V.G., et al. 2014. The role of wrack deposits for supralittoral arthropods: An example using Atlantic sandy beaches of Brazil and Spain. Estuar. Coast. Shelf Sci. 136: 61-71. http://dx.doi.org/10.1016/j.ecss.2013.11.016

Salvat B. 1964. Les conditions hydrodynamiques interstitielles des sediment meubles intertidaux et la répartition verticale de la faune endogée. C.R. Acad. Sci., Paris 259: 1567-1579.

Schlacher T.A., Thompson L. 2013. Spatial structure on oceanexposed sandy beaches: faunal zonation metrics and their variability. Mar. Ecol. Prog. Ser. 478: 43-55. http://dx.doi.org/10.3354/meps 10205

Schlacher T.A, Schoeman D.S., Jones A.R., et al. 2014. Metrics to assess ecological condition, change, and impacts in sandy beach ecosystems. J. Environ. Manage. 144: 322-335. http://dx.doi.org/10.1016/j.jenvman.2014.05.036

Sobrino I., Jiménez M.P., Ramos F. et al. 1994. Descripción de las pesquerías demersales de la Región Suratlántica Española. Bol. Inst. Esp. Oceanogr. 151: 3-79.

Souza J.R., Borzone C.A. 2000. Population dynamics and secondary production of Scolelepis squamata (Polychaeta: Spionidae) in an exposed sandy beach of southern Brazil. Bull. Mar. Sci. 67: 221-233.

Speybroeck J., Alsteens L., Vincx M., et al. 2007. Understanding the life of a sandy beach polychaete of functional importance Scolelepis squamata (Polychaeta: Spionidae) on Belgian sandy beaches (northeastern Atlantic, North Sea). Estuar. Coast. Shelf Sci. 74: 109-118. http://dx.doi.org/10.1016/j.ecss.2007.04.002

TerBraak C.J.F. 1995. Ordination. In: Jongman, R.H.G., terBraak, C.J.F., van Tongeren, O.F.R. (eds), Data Analysis in Community and Landscape Ecology. Cambridge University Press, Cambridge, United Kingdom, pp. 91-173.

Torres M.A., Coll M., Heymans J.J., et al. 2013. Food-web structure of and fishing impacts on the Gulf of Cadiz ecosystem (Southwestern Spain). Ecol. Model. 265: 26-44. http://dx.doi.org/10.1016/j.ecolmodel.2013.05.019

Trask P.D. 1950. Applied sedimentation, Jon Wiley and Sons Inc, New York. http://dx.doi.org/10.5962/bhl.title.16378

Ugolini A., Ungherese G., Somigli S., et al. 2008. The amphipod Talitrus saltator as a bioindicator of human trampling on sandy beaches. Mar. Environ. Res. 65: 349-357. http://dx.doi.org/10.1016/j.marenvres.2007.12.002 
Appendix 1. - Density (ind. $\mathrm{m}^{-2}$ ); Total species (richness); $d$, Margalef's species richness; H', Shannon-Wiener diversity index; J', Pielou evenness index; T.dens., total density per species (ind. $\mathrm{m}^{-2}$ ); Freq., species frequency; H, Hoyo; T, Terrón; Bo, Bota; Ma, Matalascañas; M, Mazagón; Cb, Costa Ballena; V, Valdelagrana; Le, Levante; C, Cortadura; Ba, Barrosa; Z, Zahara; La, Lances.

\begin{tabular}{|c|c|c|c|c|c|c|c|c|c|c|c|c|c|c|}
\hline Species composition & $\mathrm{H}$ & $\mathrm{T}$ & Bo & $\mathrm{Ma}$ & M & $\mathrm{Cb}$ & V & Le & $\mathrm{C}$ & $\mathrm{Ba}$ & $\mathrm{Z}$ & $\mathrm{La}$ & T. dens. & Freq. \\
\hline \multicolumn{15}{|l|}{ Crustacea } \\
\hline Ampelisca sp. & & & 0.27 & & & & & & & & & & 0.27 & $8 \%$ \\
\hline Apherusa sp. & 0.27 & & & & & & & & & & & & 0.27 & $8 \%$ \\
\hline Atylus swammerdami & 0.27 & 2.40 & 0.27 & & & & & & & & & & 2.93 & $25 \%$ \\
\hline Bathyporeia pelagica & & & 7.47 & & & 17.60 & & 6.13 & 1.07 & & & & 32.27 & $42 \%$ \\
\hline Bodotria pulchella & & & 0.80 & & & & & & & & & & 0.80 & $8 \%$ \\
\hline Cumella pygmaea & 2.67 & & & & & & & & & & & & 2.67 & $8 \%$ \\
\hline Cumopsis fagei & 0.53 & 0.27 & 0.27 & & & 0.27 & & 0.27 & 0.27 & 0.27 & & & 2.13 & $58 \%$ \\
\hline Diogenes pugilator & & 0.27 & 9.33 & & & & & & & & & & 9.60 & $17 \%$ \\
\hline Eocuma dollfusi & & & & & & & & 0.27 & & 0.27 & & & 0.53 & $17 \%$ \\
\hline Eurydice affinis & 2.67 & 11.20 & 1.60 & & 5.07 & 0.80 & 0.53 & 4.53 & 5.07 & & & 2.67 & 34.13 & $75 \%$ \\
\hline Eurydice pulchra & & & 2.40 & & & 3.20 & & & 0.27 & 3.20 & & & 9.07 & $33 \%$ \\
\hline Gastrosaccus sanctus & 2.13 & 2.13 & 0.53 & & 0.53 & 0.80 & 0.27 & & 0.27 & 1.07 & 4.27 & 1.87 & 13.87 & $83 \%$ \\
\hline Gastrosaccus spinifer & & 4.80 & 0.80 & & & & & 1.07 & 0.53 & 1.60 & 1.87 & & 10.67 & $50 \%$ \\
\hline Haustorius arenarius & 0.27 & & 4.27 & 2.13 & 0.27 & 93.87 & 1.60 & 0.53 & 18.13 & 5.07 & 0.27 & 4.00 & 130.40 & $92 \%$ \\
\hline Lekanesphaera cf weilli & & & 0.27 & & & 4.53 & 2.93 & 1.33 & 1.87 & & 0.27 & 1.87 & 13.07 & $58 \%$ \\
\hline Processa sp. & & & 0.27 & & & & & & & & & & 0.27 & $8 \%$ \\
\hline Liocarcinus depuratus & & & 0.27 & & & & & & & & & & 0.27 & $8 \%$ \\
\hline Mysidae sp. & & & & & & & & 0.53 & & & & & 0.53 & $8 \%$ \\
\hline Paguridae & 0.27 & & & & & & & 0.27 & & & & & 0.53 & $17 \%$ \\
\hline Pontocrates arenarius & 3.20 & 10.40 & 0.27 & 1.87 & 5.33 & 0.80 & & 0.80 & 0.80 & 12.00 & 6.93 & 5.07 & 47.47 & $92 \%$ \\
\hline Portunnus latipes & & & 1.60 & & 0.27 & 0.53 & & 0.53 & & & & & 2.93 & $33 \%$ \\
\hline Siphonoecetes sabatieri & 2.13 & 2.93 & 116.27 & & 5.60 & & & 1.60 & & & & & 128.53 & $42 \%$ \\
\hline Talitrus saltator & & 1.07 & & & 4.00 & & & 1.07 & & & 2.67 & 5.07 & 13.87 & $42 \%$ \\
\hline \multicolumn{15}{|l|}{ Polychaeta } \\
\hline Aponuphis bilineata & & & & & & & & & 0.27 & & & & 0.27 & $8 \%$ \\
\hline Capitella capitata & & & 0.27 & & & & & & & & & & 0.27 & $8 \%$ \\
\hline Dispio uncinata & & & 1.07 & & & 1.07 & & & 0.27 & 0.53 & & & 2.93 & $33 \%$ \\
\hline Eteone sp. & & & 0.53 & & & & & & & & & & 0.53 & $8 \%$ \\
\hline Flabelligeridae & & & 0.53 & & & & & 2.13 & & & & & 2.67 & $17 \%$ \\
\hline Glycera capitata & & & 0.80 & & & & & 1.33 & & & & & 2.13 & $17 \%$ \\
\hline Glycera tridactyla & & & & & & & 1.07 & 1.33 & & & & & 2.40 & $17 \%$ \\
\hline Hesionides arenaria & & & & & & & & & & 0.53 & & & 0.53 & $8 \%$ \\
\hline Magelona papilliformis & & & 2.40 & & & & & & & & & & 2.40 & $8 \%$ \\
\hline Nephthys cirrosa & 0.80 & & 2.93 & & & & 2.40 & 0.27 & 0.80 & & & & 7.20 & $42 \%$ \\
\hline Nephthys hombergii & & & & & & 0.53 & & & & & & & 0.53 & $8 \%$ \\
\hline Onuphis eremita & & & & & & & 1.87 & & & & & & 1.87 & $8 \%$ \\
\hline Ophelia radiata & 3.20 & & & & & & & & & & & & 3.20 & $8 \%$ \\
\hline Paraonis fulgens & & & & & & & & & 1.60 & 0.27 & & & 1.87 & $17 \%$ \\
\hline Phyllodocidae sp. & 5.07 & & & & & & & & & & & & 5.07 & $8 \%$ \\
\hline Saccocirrus sp. & 6.93 & 0.53 & & & 5.33 & & & & & 1.60 & 9.33 & & 23.73 & $42 \%$ \\
\hline Scolelepis squamata & 6.13 & 3.73 & 59.47 & 69.33 & 2.13 & 4.53 & 79.73 & 7.47 & 1.60 & 0.53 & 0.27 & 1.07 & 236.00 & $100 \%$ \\
\hline Spiophanes sp. & & & 0.80 & & & & & & & & & & 0.80 & $8 \%$ \\
\hline Spionidae sp1 & & & & & & & & & 0.53 & & & & 0.53 & $8 \%$ \\
\hline Spionidae sp2 & & & & & & & & & 0.27 & & & & 0.27 & $8 \%$ \\
\hline Sthenelais boa & & & 0.80 & & & & & & & & & & 0.80 & $8 \%$ \\
\hline Terebellidae sp. & & 0.27 & & & & & & & & & & & 0.27 & $8 \%$ \\
\hline \multicolumn{15}{|l|}{$\begin{array}{l}\text { Insecta } \\
\text { Inte sp. }\end{array}$} \\
\hline Carabidae sp & & & & & & & & & & 0.27 & & & 0.27 & $8 \%$ \\
\hline Coleoptera sp1 & & & & & & & & 1.87 & & & & & 1.87 & $8 \%$ \\
\hline Coleoptera sp2 & & & & & & & & 1.33 & & & & & 1.33 & $8 \%$ \\
\hline Curculionidae sp. & 0.27 & & & & & 0.27 & & & & & 0.80 & 0.27 & 1.60 & $33 \%$ \\
\hline Phaleria bimaculata & & & 0.27 & & & & & & & & 0.27 & & 0.53 & $17 \%$ \\
\hline Pogonus sp & & & & & & & & 0.27 & & & & & 0.27 & $8 \%$ \\
\hline Scarabaeidae sp. & & & & & & 0.27 & & & & & & & 0.27 & $8 \%$ \\
\hline Staphylinidae sp. & & & & & & & & & & 0.27 & 0.27 & & 0.53 & $17 \%$ \\
\hline Tenebrionidae sp. & & & & & & & & & & 0.80 & & & 0.80 & $8 \%$ \\
\hline \multicolumn{15}{|l|}{ Mollusca } \\
\hline Chamaelea gallina & & & & & & & & & 0.27 & & & & 0.27 & $8 \%$ \\
\hline Corbula gibba & & & & & & & & 0.80 & & & & & 0.80 & $8 \%$ \\
\hline Donax trunculus & & & 27.47 & 2.93 & & 1.87 & 5.33 & 1.33 & 0.53 & & & 0.53 & 40.00 & $58 \%$ \\
\hline Mactra stultorum & 0.27 & & & & & & 1.07 & & & & & & 1.33 & $8 \%$ \\
\hline Nassarius incrassatus & & & 0.27 & & & & & & & & & & 0.27 & $8 \%$ \\
\hline Nassarius vaucheri & & & 1.07 & & & & & & & & & & 1.07 & $8 \%$ \\
\hline Tapes sp. & & & & & & & & & 0.27 & & & & 0.27 & $8 \%$ \\
\hline Tellina tenuis & & & 0.53 & & & & & & & & & & 0.53 & $8 \%$ \\
\hline \multicolumn{15}{|l|}{ Nemertea } \\
\hline Nemertea sp. & 21.87 & 2.40 & 2.40 & & 0.27 & & & 0.27 & & 0.27 & 14.40 & 0.27 & 42.13 & $67 \%$ \\
\hline Density & 58.9 & 42.4 & 248.5 & 76.3 & 28.8 & 130.9 & 96.8 & 37.3 & 34.7 & 28.5 & 41.6 & 22.7 & 847.4 & \\
\hline Total species & 18 & 13 & 33 & 4 & 10 & 15 & 10 & 24 & 19 & 16 & 12 & 10 & 184 & \\
\hline$d$ & 3.15 & 2.37 & 4.68 & 0.53 & 1.92 & 2.26 & 1.53 & 4.65 & 3.70 & 3.21 & 2.18 & 2.03 & & \\
\hline $\mathrm{H}^{\prime}$ & 2.15 & 2.06 & 1.76 & 0.40 & 1.92 & 1.11 & 0.81 & 2.68 & 1.84 & 1.95 & 1.79 & 1.98 & & \\
\hline $\mathrm{J}^{\prime}$ & 0.74 & 0.80 & 0.50 & 0.29 & 0.83 & 0.41 & 0.35 & 0.84 & 0.62 & 0.70 & 0.72 & 0.86 & & \\
\hline
\end{tabular}

